\title{
ブランドの『知識/連想』と『イメージ』の関連性分析 〜テキストマイニングを応用して〜
}

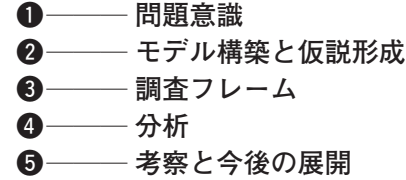

\section{黒岩 祥太 \\ 株式会社現代文化研究所}

\section{1 問題意識}

消費者が様々な商品や企業に対していだく ブランドイメージを実証的に計るための主要 な方法論として，特性形容詞句（「信頼できる」 「若々しい」など）を用い，その表現にどの程 度対象ブランドが当てはまっているのかを 7 段階尺度などで計る調査分析法（SD 法）が挙 げられる。特にブランドパーソナリティ論に 基づく実証研究では，人間の性格心理学にお ける 5 因子（BIG5）仮説を援用し，米国にお けるブランドのパーソナリティは「誠実 (Sincerity)」「刺激 (Excitement)」「能力 (Competence)」「洗練 (Sophistication)」「頑 丈 (Ruggedness)」という人間のパーソナリ ティと類似した 5 つの因子によって尺度化で きることが明らかにされた（Aaker，1997）。 またこの因子の構成要素は, 米国と日本, ス ペインなど国によって異なることも示された (Aaker et al., 2001)。更に, 日本的ブランド パーソナリティの再検証（松田, 2003）では, 日本的パーソナリティ因子が修正され，「誠実」
「刺激」「能力」「洗練」「温和」因子がその構 成要素として位置づけられた。

このようなブランドパーソナリティ論とそ の実証研究の意義は，まず，消費者がブラン ドという抽象的な存在を，完全に同一ではな いにせよ，パーソナリティという人間の性格 のメタファーを利用しながら理解していると いうことを実証的に検証したことである。要 するに人々は，ブランドに関する個々の情報 をその都度適当に繋ぎ合わせてブランド全体 のイメージを構築しているわけではなく，「ブ ランドパーソナリティという一つの全体的に まとまりを持った特性」(阿久津・石田, 2002 ) を先験的かつ擬人的なフレームとし，そこに 肉づけしていく形で，イメージを形成してい ることが明らかとなってきた。

また各種商品カテゴリーに属する様々なブラ ンド間のイメージを包含するような統一的尺度 の形成を試みたことも，ブランドパーソナリテ イ論の意義として挙げられる。すなわち，その 因子尺度に基づいて計算された各個別ブランド の因子得点を比較することで, 多種多様な商品 カテゴリーに所属する様々なブランドのイメー ジの特徵を, 比較的安定性の高い基準から端 的に特徵づけることが可能となったのである。 
以上のようにブランドパーソナリティ論は, ブランド研究とブランドの実務場面において 大きな貢献を果たしてきたといえよう。しか しながらそれらを踏まえたうえで，次のよう な二点の発展的課題を挙げることができる。

まず第一点目として，上述のような実証研 究では，概ね様々なブランド「間」に潜むパ ーソナリティイメージを抽出することに重点 がおかれているため，ある単一のブランドに 対して消費者が抱くイメージの「個人差」に ついての考察は概ね捨象されてしまっている 点が挙げられる。つまりブランドイメージ調 査から得られるデータベースの形式は, 複数 の対象ブランド×複数のサンプル（調査回答 者）×イメージ項目といった 3 相構造となる が, このうち, もっぱら複数の対象ブラン ドメイメージ項目がはらむ潜在的な関係性に 着目しており，ある単一の対象ブランドに対 する複数のサンプルメイメージ項目という関 係は概ね看過されてきたことになる。

例えば上述の Aaker（1997，2001）による 因子分析のプロセスでは，米国の場合，ある ブランドの各イメージ項目の得点データに各 サンプルの平均点を用いているし，日本の場 合は各サンプルの個票デー夕全体をそのまま 用いているものの，注棌に打いてその因子分 析の結果が，米国のように各ブランドの平均 点を用いた分析結果と類似していることを示 唆しているなど，もっぱらブランド間の相対 的な関係から得られる結果に着目している。

確かに，ある単一ブランドについてのパー ソナリティを，誰が観察しても同一な客観的 特性だと仮定してしまえば，このような前提 が成り立つかもしれない。しかしながら厳密 にいえば，あるブランドに対する印象は，ブ
ランドの発信者である企業と受信者である消 費者の間，そして消費者間相互でも異なる。 この点について新倉（2005）は，ブランドを 発信する側の思い描くブランドの理想像（「ブ ランドアイデンティティ」と定義）と，消費 者によって認知され解釈されたブランドの姿 （「ブランドイメージ」と定義）との間には 「3Cバイアス」1)によって必然的に差が生じる と論じている。この議論に付言すれば，消費 者相互間においてもこの「3Cバイアス」のか かり方は一様ではない。したがって，ある同 一のブランドに対するイメージも消費者相互 間で差が生じてくる。実際，社会心理学の対 人認知分野では，このような印象形成の個人 差も一つの主要な研究課題（池上, 2001）で あった。

では，あるブランドに対するイメージの個 人差についての考察が，ブランド研究や関連 した実務において重要である理由は何であろ うか。これはその差がどのような要因によっ て生じているのかを明らかにしていくことに よって，ブランド間の比較以上に，ブランド 構築プロセスに対して緻密で具体的な考察が 可能になると考えられる点である。

例えばパーソナリテイ論に基づくようなブ ランド「間」イメージ調査結果から，トヨタ は他企業と比較して「刺激因子」が課題であ るという考察が得られた場合を想定しょう。 このような調査結果（それ自体が問題発見と して有用であることは間違いないが）から， ではどうすればトヨタは「刺激因子」を強め ることが出来るのかという処方箋を描くこと は，それほど容易ではない。なぜならトヨ夕 と他企業とでは，ブランドを取り巻く文脈 (リーダーのパーソナリティ, 投入商品ライン 
ナップ, 経営状況, 伝統ほか) がまったく異 なっており，したがってどの要因がどの程度 「刺激因子」に効いているのかを特定すること が困難だからである。また仮にある戦略が他 企業の「刺激因子」に大きく影響を与えてい ることが判明したとしても，やはり文脈の違 いから，それと同様な戦略が，必ずしもトヨ タ・ブランドに同じょうな効果をもたらすとは 限らない。

そこでトヨタとしてはもう一つの目線を持 ち，トヨタのブランドイメージを「刺激的で ある」と感じている消費者と「刺激的ではな い」と感じている消費者との間での差を生み 出している要因についても考察すべきであろ う。つまり，異なるブランド間の場合と比較 して，ある単一ブランドに対して消費者が抱 くイメージの個人差を生じさせている要因を 特定し，好ましくない印象を持っている消費 者からブランド構築プロセス上の課題を抽出 すること（そして対処すること）は，相対的 に容易であると考えられるのである。

次に課題の第二点目として，パーソナリテ イ論に基づくようなイメージ調査と分析によ り，形容詞的なブランドイメージの特徴が明 らかになったとしても，今度はそのイメージ の特徵が，ブランドに対するどのような具体 的経験に基づく知識や連想（本稿では, 連想 をブランド知識のうちで言語化でき，かつ強 く印象づけられていて表出可能なものと仮定 する）と関連づけられて形成されているのか を明らかにする方法論が十分には開発されて いないという点が挙げられる。これは要する に，分析の結果，例えば「若々しさ」が弱い と課題が抽出できても, 今度はこの「若々し さ」という抽象的なイメージが, 消費者の頭
の中でどのような知識（例えばある製品や広 告など）と結びついて形成されているのかが 分からないということでもある。

この点に関連し，Krishnan（1996）はブラ ンドの持つ様々な連想ネットワークモデルを 理論的に仮定した。また更に，ブランドエク イティの強さの異なるブランド間で想起され る自由連想の質・量がどのように異なるのか ということも実証的に分析した。しかしなが らこの研究では，ブランド連想とブランドエ クイティが直接的に結びつけられて分析され ており，消費者の持つブランド連想とブラン ドエクイティとの間に介在すると想定される ブランドイメージについては，系統的な考察 がなされていない。

だが，社会心理学における印象形成の理論 を踏まえても，ブランドに関する具体的な知 識や連想とブランドエクイティとの間には, ブランドイメージという概念を導入した方が 妥当であるように思われるし，一方で，消費 者があるブランドに対して持つイメージの傾 向性は, 自由連想という方法論の中で表出さ れるような知識や連想によってこそ，根拠づ けられ，より具体化されると思われる。

以上の二つの課題を踏まえ, 本研究では, 第一に，単一のブランドに対するイメージと， その個人差がどのように形成されていくのか ということについて, 社会心理学における印 象形成についての理論などを応用しながらモ デル構築を行う。

次に，このモデルに基づきながら，ブラン ドについてのイメージの個人差と, その差異 に関連していると思われる連想を抽出する手 法を，ケーススタディを用いながら実証的に 展開する。なお，ケーススタディにはトヨ夕 
口図-1

連想ネットワーク（Krishnan, 1996）

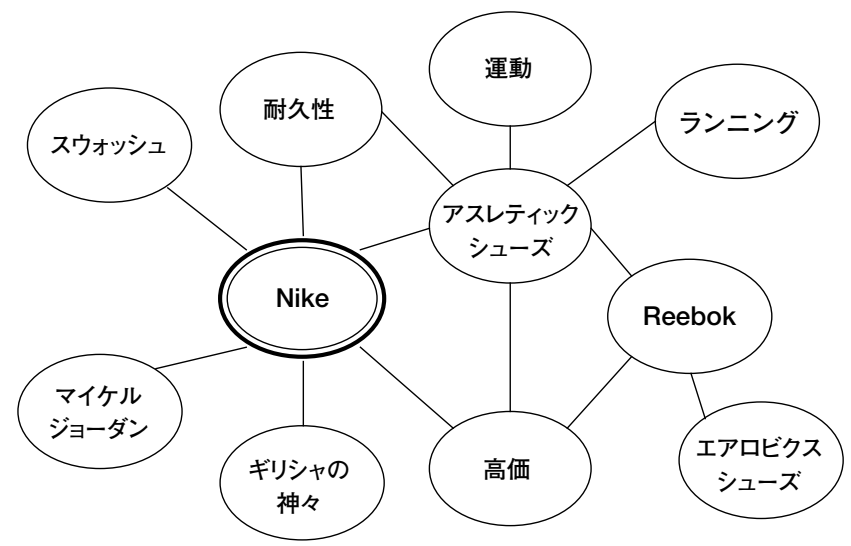

自動車に関するイメージ調査の結果を用いる。 分析対象としてトヨタ自動車を選んだ理由 は，第一に，クルマという製品は家電などと 同様，情報処理型の意思決定プロセスを忠実 にたどっており，情報源との接触が一番盛ん （清水，2006）であることから，それだけ消費 者の知識構造が深く多面的であることが期待 できるためである。そして第二に，筆者の所 属している研究所がトヨ夕自動車から比較的 情報を得やすい位置にいることから，分析の 際してコンテクストを把握しやすいと考えた からである。

\section{2) モデル構築と仮説形成}

本章では，まず対人認知についてのネット ワークモデル（宮元，2001），2段階モデル (Trope, 1986), 「ブランドのシンボリック・ ベネフィット」の知識内容と構造モデル（松 下，2004）などを応用し，「消費者のブランド に対する印象形成モデル」を構成する。その 上で実証分析へとつながる仮説を構築する。
特に「消費者のブランドに対する印象形成モ デル」については，ブランドイメージに対す る個人差がどこで生じるのかに着目しながら， 順次説明を加える。図ー2をご参照いただき たい。

第一段階として，ブランド（企業，製品ブ ランドを含む）の提供者とその他のブランド をとりまく外的な関係者が，情報やメッセー ジを放つ段階が想定できる。このうちブラン ドの提供者が放つ情報やメッセージは, 主と してマーケティング・コミュニケーション手 段によって消費者に伝えられる。Keller （1998）はマーケティング・コミュニケーショ ン手段として, 媒体広告, ダイレクト・レス ポンス広告, 場所, POP 広告, 流通業者向け プロモーション，消費者向けプロモーション， イベントマーケティングとスポンサーシップ, パブリシティと $\mathrm{PR}$ ，人的販売などを挙げてい る。これらの手段を用いて為されるコミュニ ケーションはブランドの提供者から消費者へ と必ずしも一方通行というわけではないが, 消費者という視点からすれば，それらの情報 
消費者のブランドに対する印象形成モデル

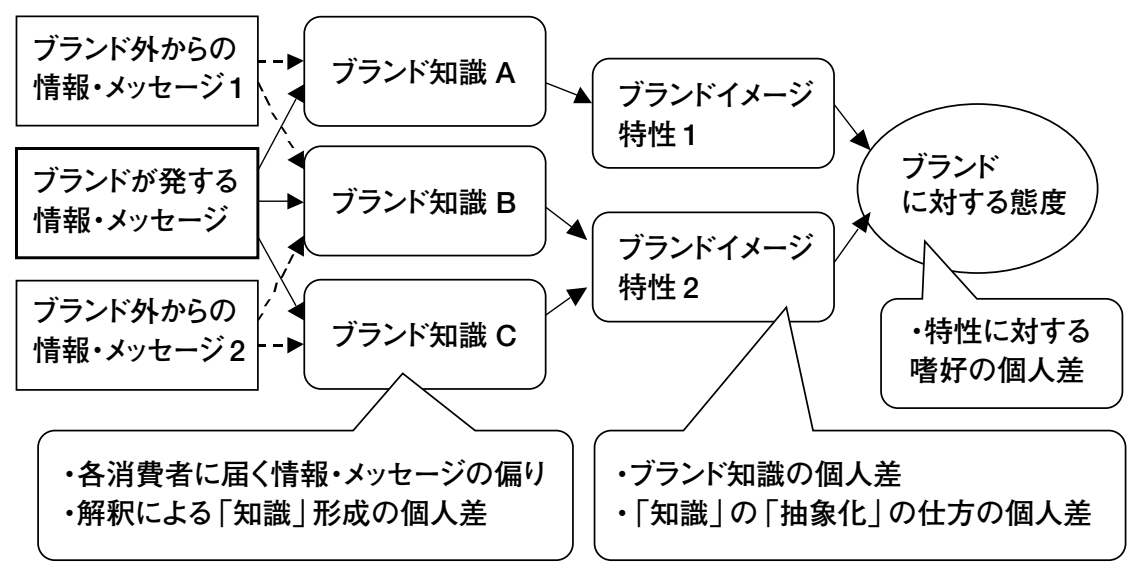

やメッセージは受け止められるものとして便 宜的に捉えることも出来よう。

次に第二段階として，ブランドに関するメ ッセージが消費者に経験され，個々の消費者 をとりまく主観的な文脈の中でブランド知識 として蓄積される段階が想定される。青木 （1993）はこのブランド知識について，Tulving（1983）の議論に基づき類型化を試みてい る。それによれば，まずブランド知識は「宣 言的知識」と「手続き的知識」に大別される。 この両者の違いは，前者が基本的に命題の形 で表象可能な知識であるのに対し，後者はそ れが困難な手続きや方法・技能についての知 識（例えば泳ぎ方や自転車の乗り方など）で ある点である。そして「宣言的知識」は「概 念的知識」と「エピソード的知識」に分類さ れる。前者は事実, 概念, 言葉の意味など, 超時間的・超空間的な知識であるのに対し, 後者は時間的・空間的に限定された経験につ いての記憶に基づく知識である。このように 一口にブランド知識といっても，様々な様態
が考えられる。また，「言われてみればそうだ った」というような，助成されてはじめて顕 在化するような潜在的知識も存在するように， 個々の知識要素には強弱も想定されよう。

そしてこの段階で，消費者によるブランド 知識の個人差が次の二つの契機によって生じ ることになる。その一つは, 消費者に到達す るブランドに関連した情報やメッセージの偏 りである。当然ではあるが，ある単一の企業 に対しても，消費者によって関与度やコンタ クトポイントは異なる。したがって誰もが同 じ情報を受け取り，同じ経験を共有している 訳ではない。またもう一つは，消費者のブラ ンド知識の恣意性によるものである。すなわ ちブランド知識とは，消費者が自身をとりま く文脈の中で，独自の主観的な解釈フレーム を用いて解釈されるものであり，決してブラ ンドについての受け取った情報やメッセージ 「そのもの」ではない。したがって，例え同じ 情報やメッセージを受け取ったとしても，必 ずしも全ての消費者間で，同じブランド知識 
として解釈され蓄積される訳ではない。

次に第三段階として，ブランド知識に基づ いてブランドイメージ特性が推論される段階 が想定できる。ブランドイメージ特性とは, 上述のブランドパーソナリティ因子を尺度と した場合に，実際に各消費者がそのブランド に対して感じるその尺度の強弱（因子得点） に相当する。なお印象形成の研究では，その 印象を形成する人の能力や調査・分析法など によって他者パーソナリティ把握のための次 元数は異なっており (林, 1978 ほか)，またブ ランドごとにパーソナリティ特性の次元数を 特定した実証研究（Caprar et al., 2001）にお いても，必ずしも 5 因子が妥当だという結論 は導出されていない。したがってイメージ特 性も，必ずしも5つの尺度得点からなるとは 限らないと考える。

そしてこのブランド知識をブランドイメー ジ特性に関連づけるプロセスは，「特性推論」 と呼ばれる。「特性推論」の際に用いられる知 識は「概念的知識 (意味記憶)」と「エピソー ド的知識（エピソード記憶）」である（山本 2006)。このプロセスを通じ，人々はブランド に対する雑多な知識を，より抽象化・統合化 したイメージ特性へと関連づけて捉えること で，ブランドの特徴をより単純化して効率的 に把握していると考えられる。なお上述のよ うに，ブランドに関連した知識には個人差が あることから，イメージ特性にも個々人によ って差が生じると考えられる。この点が本研 究では重要なポイントとなる。

最後に第四段階として，ブランドイメージ 特性を束ねる，そのブランドに対する各消費 者の包括的な態度，すなわち好意度というも のが想定される。類似の分析としては, 例え
ば後藤（2006）は共分散構造解析を用い，5 つの製品カテゴリーでブランドイメージと好 意や購買意向の関係を検証している。本研究 では因子分析や主成分分析と重回㷌分析を組 み合わせる方法論（神宮, 1996; 朝野, 1995 な ど）を参考とし，ブランドに対する好意度は 各パーソナリティイメージ因子の因子得点 （イメージ特性）を説明変数とする線形関係で 表現できるものと想定する。

以上，「消費者のブランドに対する印象形成 モデル」を素描してきたが，今回の実証分析 で特に着目すべき点は，あるブランドに対す るブランド連想の偏り（それはブランド知識 の偏りを端的に表現していると仮定される） が，当該ブランドに対するイメージ特性の個 人差と関連しあっているのか，またこの関連 には妥当性があるのかという点である。更に， そこから得られた知見が，ブランド戦略に対 して何らかの有用な示唆を与えられそうかと いうことも重要である。それらも踏まえて, 次のような三つの分析仮説を導き出した。

$\mathrm{H} 1$ ：単一ブランド（トヨタブランド）に対 する印象の個人差の因子分析結果は, 既存の対人認知構造の分析結果と類似 している。

$\mathrm{H} 2$ ：各人のあるブランドに対する全体的態 度（好意度）は，ブランドのイメージ 特性をどのように感じているのかによ って影響を受ける。

$\mathrm{H} 3$ : 各人の, 単一のブランドに対するイメ ージ特性の差は, ブランド連想の差と 関連性があり，かつそれらの間には妥 当性がある。

以上の仮説は, 分析の便宜上, 上述した消 費者のブランドに対する印象形成モデルを概 
ね逆から辿っている。この順で分析を進めて いく。

\section{3) 調査フレーム}

分析に用いるデータは 2006 年 10 月 12 ～ 20 日に株式会社現代文化研究所が実施した自動 車についてのインターネット調査で得たもの を用いる。なお実査自体は株式会社ネットマ イルに委託し，クルマ世帯保有者を 2079 サン プル集めた。また，性年代や地域的な偏りを 考慮し，各地域ごとに割付を行った。サンプ ル設定は表一1のとおりである。

この調査の中で，「あなたが『トヨタブラン ド』から連想することを自由にお書きくださ い。（自身の体験，エピソード，製品，広告， 販売店，イメージ等，なんでも結構です。最 大七つまで，なるべくたくさんお書きくださ い。」という設問と七つの自由回答用の空欄 からブランド連想データを獲得した。

またこれとは別に，「各メーカーのイメージ について、それぞれ 7 段階で評価してくださ
い」という設問で「積極的な-消極的な」「責 任感のある-責任感のない」といった 28 の両 極性の形容詞対を評価してもらい，ブランド イメージのデータを獲得した。これらの形容 詞対については, 対人認知構造把握（林, 1978; 宮本, 2001 など）の際に利用される傾向 の強い 20 項目をべースとし，それ以外にブラ ンド調査には必要だと思われる性別「男性的 な-女性的な」や強さ「強い-弱い」など，8項 目の形容詞対を加えた。設問に対人認知尺度 の形容詞対を用いた理由は, 消費者にとって ブランドというものが，まずは「自分自身」 というょりも「他者」として認知されると考 えたためである。

またこれらとは別に，トヨタに対する好意 度を「非常に好き」から「まったく好きでは ない」の 7 段階で把握した。また, 自由連想 の偏りをなるべくなくすため, 先に自由連想 についての設問を行った。

表—— 1

調査概要

調査対象： 株式会社ネットマイルのモニターで, 次の条件に当てはまる人。クルマ世帯保有者（主運転

車保有者中心) で，以前ブランドデータバンク株式会社の第四期調査に答えていただいた 方。(実査自体は株式会社ネットマイルに委託)

サンプル数：合計2079人 (回収ベース)

\begin{tabular}{|c|c|c|c|c|c|c|c|}
\hline \multicolumn{2}{|l|}{ 構成 } & \multicolumn{5}{|c|}{ 地域 } & \multirow[t]{2}{*}{ 総計 } \\
\hline 性別 & 年代 & 関東 & 近畿 & 㭝州·四囯縄 & 海・部・北陸 & 北海道・ & \\
\hline \multirow[t]{5}{*}{ 男性 } & 20代 & 46 & 46 & 46 & 46 & 46 & 230 \\
\hline & 30代 & 46 & 46 & 46 & 46 & 46 & 230 \\
\hline & 40代 & 46 & 46 & 46 & 46 & 46 & 230 \\
\hline & 50代 & 46 & 46 & 46 & 46 & 46 & 230 \\
\hline & 60代以上 & 102 & 53 & 28 & 30 & 19 & 232 \\
\hline \multirow[t]{5}{*}{ 女性 } & 20代 & 46 & 46 & 46 & 46 & 46 & 230 \\
\hline & 30代 & 46 & 46 & 46 & 46 & 46 & 230 \\
\hline & 40代 & 46 & 46 & 46 & 46 & 46 & 230 \\
\hline & 50代 & 50 & 37 & 37 & 37 & 31 & 192 \\
\hline & 60代以上 & 17 & 9 & 8 & 9 & 2 & 45 \\
\hline \multicolumn{2}{|l|}{\begin{tabular}{|l|} 
総計 \\
\end{tabular}} & 491 & 421 & 395 & 398 & 374 & 2079 \\
\hline
\end{tabular}




\section{4- 分析}

\section{1. ブランドイメージの因子分析}

まず，トヨタに対する 28 の形容詞対による ブランドイメージ回答に対し，因子分析（主 因子法，バリマックス回転）を行った。その 結果，回転前の固有值 1 以上という条件で 5 因子が抽出され, 解釈可能性からこれらを採 用した。なお，5因子の回転前累積寄与率は 59.9\%であった。表一 2 が基本的な統計量と因 子分析の結果である。

第 1 因子に負荷量が高い項目は，「重厚な」 「ステータス性の高い」「強い」「責任感のある」 などであり，「強さ・重厚さ」を表していると 解釈できた。第 2 因子に負荷量が高い項目は 「人のよい」「恥ずかしがりの」「親切な」「信 頼できる」などであり，「人のよさ・信頼感」
を表していると解釈できた。さらに第 3 因子 は「ひとなつっこい」「親しみやすい」などの 因子負荷量が高いことから「親しみやすさ」, 第 4 因子は「自信のある」「意欲的な」「社交 的な」などの因子負荷量が高いことから「活 動性」を表現していると解釈した。最後に第 5 因子は，「若々しい」「個性的な」の因子負 荷量が高いことから，そのまま「個性・若さ」 因子と命名した。

なお，対人認知研究においては，人が他者 のパーソナリティを認知する場合の印象判断 に際し，「個人的親しみやすさ」, 知的・課題 関連的側面における尊敬の判断としての「社 会的望ましさ」, そして「活動性」の主要な 3 次元を働かせると整理される（林, 1978; 宮本, 2001)。本研究では「強さ・重厚さ」因子が対 人認知研究の「社会的望ましさ」と，「人のよ さ・信頼感」因子および「親しみやすさ」因

表— 2

トヨタイメージの因子分析：回転後の因子負荷量

\begin{tabular}{|c|c|c|c|c|c|c|c|}
\hline \multirow[t]{2}{*}{ 回転後の因子行列 } & \multicolumn{5}{|c|}{ 因子 } & \multicolumn{2}{|c|}{ 記述統計量 } \\
\hline & $\begin{array}{l}\text { 強さ·重厚 } \\
\text { さ }\end{array}$ & $\begin{array}{l}\text { 人のよさ・ } \\
\text { 信頼感 }\end{array}$ & $\begin{array}{l}\text { 親しみやす } \\
\text { さ }\end{array}$ & 活動性 & 個性·若さ & 平均値 & 標準偏差 \\
\hline 重厚な－ 軽薄な & 0.695 & 0.159 & 0.178 & 0.117 & 0.032 & 4.81 & 1.13 \\
\hline 堂々とした一舫屈な & 0.631 & 0.138 & 0.215 & 0.304 & 0.093 & 5.14 & 1.26 \\
\hline ステータ之性の高い-ステータス性の低心゙ & 0.611 & 0.084 & 0.149 & 0.222 & 0.164 & 5.07 & 1.34 \\
\hline 強心一弱心 & 0.586 & -0.014 & 0.141 & 0.393 & 0.097 & 5.09 & 1.21 \\
\hline 一貫性のある-二貫性のない* & 0.522 & 0.173 & 0.279 & 0.121 & 0.220 & 4.61 & 1.24 \\
\hline 洗練された-洗練されていない* & 0.513 & 0.187 & 0.168 & 0.233 & 0.408 & 4.75 & 1.24 \\
\hline 責任感のある-責任感 $\phi な \omega$ & 0.499 & 0.247 & 0.369 & 0.228 & 0.071 & 4.93 & .1 .31 \\
\hline 分別のある-無分別な & 0.466 & 0.265 & 0.449 & 0.173 & 0.097 & 4.68 & 1.15 \\
\hline 男性的な一女性的な* & 0.452 & -0.130 & -0.040 & 0.015 & 0.098 & 4.36 & 0.92 \\
\hline 人のよい-ᄉのわるい & 0.112 & 0.643 & 0.342 & 0.307. & 0.085 & .4 .41 & 0.98 \\
\hline 感 & 0.224 & 0.595 & 0.328 & 0.417 & 0.153 & 4.69 & 1.19 \\
\hline かわいらしい-に<5LW & -0.070 & 0.580 & 0.230 & 0.161 & 0.237 & 4.08 & 0.77 \\
\hline 親切な一不親切な & 0.197 & 0.550 & 0.352 & 0.412 & 0.045 & 4.66 & 1.13 \\
\hline 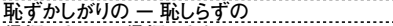 & -0.008 & 0.541 & 0.060 & 0.004 & 0.058 & 3.95 & 0.66 \\
\hline 信頼できる-信頼できない* & 0.355 & 0.454 & 0.192 & 0.401 & -0.039 & 5.30 & 1.39 \\
\hline 慎重な一軽率な & 0.366 & 0.448 & 0.188 & 0.242 & -0.179 & 4.59 & 1.04 \\
\hline ひとなつっこいー近づきがたい & -0.007 & 0.128 & 0.662 & 0.203 & 0.193 & 4.31 & 0.97 \\
\hline 親 & 0.192 & 0.216 & 0.557 & 0.223 & 0.214 & 4.74 & 1.27 \\
\hline 心の゙ンろいー心のせまい & 0.383 & 0.255 & 0.543 & 0.155 & 0.210 & 4.49 & 1.05 \\
\hline 気長な一短容な & 0.322 & 0.166 & 0.508 & 0.026 & -0.024 & 4.33 & 0.86 \\
\hline なまいきでないーなまいきな & 0.146 & 0.314 & 0.453 & 0.005 & 0.102 & 4.19 & 1.00 \\
\hline 自信のある－自信のない & 0.414 & 0.197 & 0.052 & 0.635 & -0.041 & 5.22 & 1.23 \\
\hline 意欲的な一無気力な & 0.318 & 0.295 & 0.100 & 0.618 & 0.230 & 4.81 & 1.11 \\
\hline 社艾的なー非社艾的な & 0.207 & 0.318 & 0.260 & 0.542 & 0.033 & 4.71 & 1.008 \\
\hline 積極的な一消極的な & 0.392 & -0.036 & 0.223 & 0.431 & 0.383 & 4.74 & 118 \\
\hline うきうきした 一沈んだ & 0.089 & 0.381 & 0.191 & 0.410 & 0.282 & 4.30 & 0.83 \\
\hline 若々しいー若々しくない* & 0.077 & 0.080 & 0.195 & 0.043 & 0.697 & 3.91 & 1.13 \\
\hline 個性的な一個性的でない゙ & 0.277 & 0.131 & 0.084 & 0.052 & 0.692 & 3.98 & 1.28 \\
\hline 嗣与率 & 14.4 & 10.8 & 9.9 & 9.6 & 6.4 & & \\
\hline
\end{tabular}


子が「個人的親しみやすさ」と，更に「活動 性」因子が「活動性」とそれぞれ対応してい ると概ね判断できる。また「個性・若さ」因 子は今回調査において，独自に抽出された。

\section{2. ブランドイメージ特性の重回帰分析}

次に, 前節で導出された因子を説明変数, トヨタブランドに対する好意度を被説明変数 とする重回帰分析を行った。結果は表一3の とおりである。

この結果から，各イメージ因子とも好意度 に関連していること，特に「人のよさ・信頼 感」（標準偏回帰係数 $0.375 ）$,「個性・若さ」 （0.358）が強く関連していることが明らかと なった。また決定係数は 0.406 であり，経験 的にみて同種の調査の中ではそれほど高くは ない。しかしながら両極性の形容詞対に対す る評価法の場合，単極性の形容詞に対する評 価法（例えば「信頼できる」がどの程度当て はまるかを 7 段階で評価する方法）と比較し て，認知度を介した擬似相関（あまり知らな ければ形容詞も当てはまらないし, 好意度も 低い）などを相対的に抑えることができてい

\section{表—— 3}

トヨタイメージ因子と好意度との重回帰分析

モデルのあてはまり
\begin{tabular}{|l|r|}
\hline 重相関係数 & 0.637 \\
\hline 決定係数 & 0.406 \\
\hline F値 & 283.8 \\
\hline 有意確率 $(\mathrm{P}$ 值) & 0.000 \\
\hline
\end{tabular}

\begin{tabular}{|l|r|r|} 
係数 \\
\hline 説明変数 & 標準偏回帰係数 & 単相関係数 \\
\hline 強さ·重厚さ & 0.229 & 0.267 \\
\hline 人のよさ·信頼感 & 0.375 & 0.419 \\
\hline 親しみやすさ & 0.175 & 0.290 \\
\hline 活動性 & 0.094 & 0.207 \\
\hline 個性·若さ & 0.330 & 0.358 \\
\hline
\end{tabular}

被説明変数: トヨタブランド好意度

*標準偏回帰係数は, すべて1\%水準で有意
ると推測されたため, この程度の值が妥当で あると考えた。

\section{3. テキストマイニングによるブランド知識/ 連想の導出}

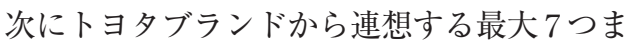
での自由回答をテキストマイニングにかけ，各 サンプルが挙げているキーワード（ブランド連 想の要素）を導出した。テキストマイニングに は TRUETELLER（株式会社野村総合研究所） を用い，各回答を単語単位に分割する形態素解 析とそこからの単語データベース化, 辞書によ る新語登録, 類似語のまとめ上げ，無意味語 (助詞, 助動詞ほか不明語）の削除を行った。 その結果, 合計で 3649 種類 20880 キーワード (1 サンプルの中で重複して導出されたキーワ ードは 1 件とカウント）を抽出した。サンプル が 2079 人なので，一人当たり平均 10.0 の異な りワードを挙げたことになる。

また一方で，4.1節の因子分析から導出した パーソナリティイメージの 5 因子を基準とし， 各サンプルを因子得点の高低ごとに 5 回セグ メント化した。セグメントの基準はそれぞれ の因子得点について，0.35より高い人を「そ のイメージが相対的に強い人」 0.35 以下で0.35 以上を「そのイメージが相対的に普通の 人」, $-0.35 よ り$ 低い人を「そのイメージが相 対的に弱い人」と定義した。 0.35 という基準 は便宜的であるが，因子得点の分布から，概 ねサンプルを三分割できる得点ということで 設定した。各セグメントのサンプル数は表ー4 のとおりである。

そして, このサンプル群ごとに, テキスト マイニングの結果からキーワードの出現件数 と出現確率を計算した。結果の概略（上位 30 
表— 4

各イメージ特性因子の因子得点ごとのサンプル分布

\begin{tabular}{|c|c|c|c|c|c|c|c|c|}
\hline \multirow{3}{*}{$\begin{array}{l}\text { 因子 } \\
\text { 強さ·重厚さ }\end{array}$} & \multicolumn{6}{|c|}{ 因子得点区分ごとのサンプル数と比率 } & \multirow{2}{*}{\multicolumn{2}{|c|}{ 合計 }} \\
\hline & \multicolumn{2}{|c|}{$\begin{array}{c}\text { 高 } \\
(>0.35)\end{array}$} & \multicolumn{2}{|c|}{$\begin{array}{c}\text { 中 } \\
(0.35 \geqq か つ-0.35)\end{array}$} & \multicolumn{2}{|c|}{$\begin{array}{c}\text { 低 } \\
(-0.35>)\end{array}$} & & \\
\hline & 686 & $33 \%$ & 595 & $29 \%$ & 798 & $38 \%$ & 2079 & $100 \%$ \\
\hline 人のよさ·信頼感 & 558 & $27 \%$ & 1061 & $51 \%$ & 460 & $22 \%$ & 2079 & $100 \%$ \\
\hline 親しみやすさ & 538 & $26 \%$ & 972 & $47 \%$ & 569 & $27 \%$ & 2079 & $100 \%$ \\
\hline 活動性 & 664 & $32 \%$ & 608 & $29 \%$ & 807 & $39 \%$ & 2079 & $100 \%$ \\
\hline 個性·若さ & 605 & $29 \%$ & 908 & $44 \%$ & 566 & $27 \%$ & 2079 & $100 \%$ \\
\hline
\end{tabular}

表—— 5

各イメージ因子の因子得点ごとのサンプル分布

\begin{tabular}{|c|c|c|c|c|c|c|c|c|c|c|c|c|c|c|c|c|c|c|}
\hline \multirow[b]{2}{*}{ No } & \multirow[b]{2}{*}{ キーワード } & \multicolumn{2}{|c|}{ 全体 } & \multicolumn{3}{|c|}{ 強さ·重厚さ } & \multicolumn{3}{|c|}{ 人のよさ•信頼感 } & \multicolumn{3}{|c|}{ 親しみやすさ } & \multicolumn{3}{|c|}{ 活動性 } & \multicolumn{3}{|c|}{ 個性·若さ } \\
\hline & & 件数 & $\begin{array}{l}\text { 出現 } \\
\text { 確率 }\end{array}$ & 高 & 中 & 低 & 高 & 中 & 低 & 高 & 中 & 低 & 高 & 中 & 低 & 高 & 中 & 低 \\
\hline & サンプル数 & 2079 & & 686 & 595 & 798 & 558 & 1061 & 460 & 538 & 972 & 569 & 664 & 608 & 807 & 605 & 908 & 566 \\
\hline 1 & カローラ & 343 & $16.5 \%$ & $17.2 \%$ & $.0 \%$ & $14.8 \%$ & $15.6 \%$ & $16.6 \%$ & $17.4 \%$ & $8.4 \%$ & 16.5 & $.8 \%$ & $19.7 \%$ & $17.8 \%$ & $2.9 \%$ & $16.0 \%$ & $16.6 \%$ & $6.8 \%$ \\
\hline 2 & 世界 & 331 & $15.9 \%$ & $21.6 \%$ & $8 \%$ & $11.2 \%$ & $17.2 \%$ & & $6.7 \%$ & $.9^{\circ}$ & 1 & $.4 \%$ & $21.4 \%$ & $16.4 \%$ & $.0 \%$ & $19.0 \%$ & & $4.0 \%$ \\
\hline 3 & トップ & 293 & $14.1 \%$ & $15.6 \%$ & $.5 \%$ & $11.8 \%$ & $147 \%$ & $136 \%$ & $14.6 \%$ & 1 & 14.3 & $3.7 \%$ & $14.8 \%$ & $16.4 \%$ & $1.8 \%$ & $15.4 \%$ & & $3.3 \%$ \\
\hline 4 & 良W & 292 & $14.0 \%$ & $15.5 \%$ & $15.3 \%$ & $11.9 \%$ & $18.5 \%$ & $12.2 \%$ & $13.0 \%$ & $15.4 \%$ & $12.2 \%$ & $15.8 \%$ & $17.0 \%$ & $13.0 \%$ & $12.4 \%$ & $18.3 \%$ & $11.3 \%$ & $13.8 \%$ \\
\hline 5 & 安灾 & 251 & $12.1 \%$ & $15.5 \%$ & $13.6 \%$ & $8.0 \%$ & $15.2 \%$ & $11.2 \%$ & $10.2 \%$ & $14.1 \%$ & $10.7 \%$ & $12.5 \%$ & $14.6 \%$ & $12.3 \%$ & $9.8 \%$ & $10.6 \%$ & $12.8 \%$ & $12.5 \%$ \\
\hline 6 & クラウン & 224 & $10.8 \%$ & $13.0 \%$ & $11.9 \%$ & $8.0 \%$ & $12.9 \%$ & $9.8 \%$ & $10.4 \%$ & $12.5 \%$ & $10.3 \%$ & $10.0 \%$ & $12.2 \%$ & $12.2 \%$ & $8.6 \%$ & $10.4 \%$ & $11.2 \%$ & $10.4 \%$ \\
\hline 7 & ハイブリッド & 224 & $10.8 \%$ & $11.4 \%$ & $13.9 \%$ & $7.9 \%$ & $12.0 \%$ & $9.0 \%$ & $13.3 \%$ & $12.6 \%$ & $10.5 \%$ & $9.5 \%$ & $13.6 \%$ & $12.0 \%$ & $7.6 \%$ & $13.4 \%$ & $9.3 \%$ & $10.4 \%$ \\
\hline 8 & $\mathrm{~F} 1$ & 198 & $9.5 \%$ & $10.9 \%$ & $10.3 \%$ & $7.8 \%$ & $10.9 \%$ & $8.9 \%$ & $9.3 \%$ & $10.6 \%$ & $9.7 \%$ & $8.3 \%$ & $10.5 \%$ & $12.3 \%$ & $6.6 \%$ & $11.7 \%$ & $7.8 \%$ & $9.9 \%$ \\
\hline 9 & 多W & 191 & $9.2 \%$ & $7.3 \%$ & $9.6 \%$ & $10.5 \%$ & $8.4 \%$ & $8.6 \%$ & $11.5 \%$ & $9.7 \%$ & $8.5 \%$ & $9.8 \%$ & $10.4 \%$ & $9.9 \%$ & $7.7 \%$ & $12.4 \%$ & $7.5 \%$ & $8.5 \%$ \\
\hline 10 & 高級 & 182 & $8.8 \%$ & $14.1 \%$ & $7.1 \%$ & $5.4 \%$ & $9.3 \%$ & $8.5 \%$ & $8.7 \%$ & $6.3 \%$ & $7.9 \%$ & $12.5 \%$ & $11.0 \%$ & $6.6 \%$ & $8.6 \%$ & $9.9 \%$ & $90 \%$ & $7.1 \%$ \\
\hline 11 & レクス & 174 & $8.4 \%$ & $9.9 \%$ & $8.7 \%$ & $6.8 \%$ & $8.1 \%$ & $8.6 \%$ & $8.3 \%$ & $9.3 \%$ & $7.8 \%$ & $8.4 \%$ & $10.1 \%$ & $9.9 \%$ & $5.8 \%$ & $7.8 \%$ & $7.3 \%$ & $10.8 \%$ \\
\hline 12 & 售頼 & 174 & $8.4 \%$ & $11.1 \%$ & $8.9 \%$ & $5.6 \%$ & $12.4 \%$ & $7.4 \%$ & $5.7 \%$ & $8.2 \%$ & 8.3 & $8.6 \%$ & $11.1 \%$ & $8.7 \%$ & $5.8 \%$ & $8.3 \%$ & $9.0 \%$ & $7.4 \%$ \\
\hline 13 & ある & 171 & $8.2 \%$ & $9.2 \%$ & $9.2 \%$ & $6.6 \%$ & $10.2 \%$ & $7.8 \%$ & $6.7 \%$ & $7.8 \%$ & $7.6 \%$ & $9.7 \%$ & $9.2 \%$ & $8.2 \%$ & $7.4 \%$ & $10.6 \%$ & $7.7 \%$ & $6.5 \%$ \\
\hline 14 & 簐 & 149 & $7.2 \%$ & $7.1 \%$ & $7.1 \%$ & $7.3 \%$ & $9.0 \%$ & $6.3 \%$ & $7.0 \%$ & $7.8 \%$ & $7.2 \%$ & $6.5 \%$ & $8.3 \%$ & $8.2 \%$ & $5.5 \%$ & $7.9 \%$ & $5.5 \%$ & $9.0 \%$ \\
\hline 15 & 環境 & 133 & $6.4 \%$ & $7.7 \%$ & $5.7 \%$ & $5.8 \%$ & $9.7 \%$ & $5.4 \%$ & $4.8 \%$ & $8.9 \%$ & 5 & $5.8 \%$ & $8.7 \%$ & $6.4 \%$ & $4.5 \%$ & $8.6 \%$ & $5.4 \%$ & $5.7 \%$ \\
\hline 16 & プリゥス & 131 & $6.3 \%$ & $8.5 \%$ & $5.9 \%$ & $4.8 \%$ & $7.7 \%$ & $5.7 \%$ & $6.1 \%$ & $7.2 \%$ & $6.9 \%$ & $4.4 \%$ & $6.8 \%$ & $8.1 \%$ & $4.6 \%$ & $7.8 \%$ & $5.0 \%$ & $6.9 \%$ \\
\hline 17 & 大企業 & 125 & $6.0 \%$ & $5.5 \%$ & $7.1 \%$ & $5.6 \%$ & $4.7 \%$ & $6.0 \%$ & $7.6 \%$ & $6.3 \%$ & $6.6 \%$ & $4.7 \%$ & $6.3 \%$ & $5.6 \%$ & $6.1 \%$ & $4.5 \%$ & $6.3 \%$ & $7.2 \%$ \\
\hline 18 & 13 & 124 & $6.0 \%$ & $8.9 \%$ & $5.9 \%$ & $3.5 \%$ & $5.9 \%$ & $5.7 \%$ & $6.5 \%$ & $7.6 \%$ & $5.7 \%$ & $4.9 \%$ & $8.1 \%$ & $5.9 \%$ & $4.2 \%$ & $7.9 \%$ & $5.5 \%$ & $4.6 \%$ \\
\hline 19 & 莗秏 & 122 & $5.9 \%$ & $5.5 \%$ & $6.1 \%$ & $6.0 \%$ & $5.7 \%$ & $6.1 \%$ & $5.4 \%$ & $6.5 \%$ & $5.6 \%$ & $5.8 \%$ & $7.5 \%$ & $5.8 \%$ & $4.6 \%$ & $7.3 \%$ & $4.8 \%$ & $6.0 \%$ \\
\hline 20 & 㗊算 & 114 & $5.5 \%$ & $6.9 \%$ & $6.4 \%$ & $3.6 \%$ & $8.1 \%$ & $5.1 \%$ & $3.3 \%$ & $6.7 \%$ & 4.4 & $6.2 \%$ & $59 \%$ & $6.7 \%$ & $4.2 \%$ & $4.0 \%$ & $4.7 \%$ & $8.3 \%$ \\
\hline 21 & 高 & 112 & $5.4 \%$ & $6.7 \%$ & $4.9 \%$ & $4.6 \%$ & $4.5 \%$ & $5.3 \%$ & $6.7 \%$ & $3.7 \%$ & 4.5 & $8.4 \%$ & $5.1 \%$ & $4.9 \%$ & $5.9 \%$ & $5.8 \%$ & $4.6 \%$ & $6.2 \%$ \\
\hline 22 & 堅実 & 111 & $5.3 \%$ & $6.7 \%$ & $6.4 \%$ & $3.4 \%$ & $7.2 \%$ & $4.7 \%$ & $4.6 \%$ & $7.4 \%$ & $4.3 \%$ & $5.1 \%$ & $5.0 \%$ & $5.4 \%$ & $5.6 \%$ & $3.6 \%$ & $4.4 \%$ & $8.7 \%$ \\
\hline 23 & 愛知県 & 101 & $4.9 \%$ & $5.8 \%$ & $3.7 \%$ & $4.9 \%$ & $3.9 \%$ & $4.5 \%$ & $6.7 \%$ & $5.8 \%$ & $3.5 \%$ & $6.3 \%$ & $4.8 \%$ & $5.8 \%$ & $4.2 \%$ & $4.3 \%$ & $4.4 \%$ & $6.2 \%$ \\
\hline 24 & 売る & 100 & $4.8 \%$ & $4.7 \%$ & $4.9 \%$ & $4.9 \%$ & $4.5 \%$ & $4.1 \%$ & $6.7 \%$ & $5.0 \%$ & 4.0 & $6.0 \%$ & $5.6 \%$ & $4.9 \%$ & $4.1 \%$ & $4.5 \%$ & $4.8 \%$ & $5.1 \%$ \\
\hline 25 & 安定 & 99 & $4.8 \%$ & $5.4 \%$ & $5.0 \%$ & $4.0 \%$ & $5.7 \%$ & $5.6 \%$ & $1.7 \%$ & $4.8 \%$ & 5.8 & $3.0 \%$ & $3.9 \%$ & $4.8 \%$ & $5.5 \%$ & $3.3 \%$ & $4.5 \%$ & $6.7 \%$ \\
\hline 26 & 販党店 & 95 & $4.6 \%$ & $3.9 \%$ & $4.2 \%$ & $5.4 \%$ & $4.3 \%$ & $4.8 \%$ & $4.3 \%$ & $4.8 \%$ & $5.0 \%$ & $3.5 \%$ & $5.4 \%$ & $4.8 \%$ & $3.7 \%$ & $6.4 \%$ & $4.1 \%$ & $3.4 \%$ \\
\hline 27 & 広告 & 92 & $4.4 \%$ & $4.4 \%$ & $4.5 \%$ & $4.4 \%$ & $6.1 \%$ & $3.2 \%$ & $5.2 \%$ & $5.0 \%$ & $3.8 \%$ & $4.9 \%$ & $4.2 \%$ & $5.4 \%$ & $3.8 \%$ & $6.8 \%$ & $3.4 \%$ & $3.5 \%$ \\
\hline 28 & 高級莗 & 89 & $4.3 \%$ & $6.1 \%$ & $4.2 \%$ & $28 \%$ & $3.2 \%$ & $5.1 \%$ & $3.7 \%$ & $2.6 \%$ & $3.8 \%$ & $6.7 \%$ & $5.0 \%$ & $5.3 \%$ & $3.0 \%$ & $5.6 \%$ & $3.5 \%$ & $4.1 \%$ \\
\hline 29 & $\$ \omega$ & 87 & $4.2 \%$ & $3.2 \%$ & $4.7 \%$ & $4.6 \%$ & $4.3 \%$ & $4.1 \%$ & $4.3 \%$ & $3.3 \%$ & 4.4 & $4.6 \%$ & $4.5 \%$ & $3.8 \%$ & $4.2 \%$ & $4.1 \%$ & $3.2 \%$ & $5.8 \%$ \\
\hline 30 & 安全 & 85 & $4.1 \%$ & $6.1 \%$ & $3.5 \%$ & $2.8 \%$ & $7.7 \%$ & $2.8 \%$ & $2.6 \%$ & $3.5 \%$ & 4.1 & $4.6 \%$ & $4.7 \%$ & $4.9 \%$ & $3.0 \%$ & $4.5 \%$ & $3.4 \%$ & $4.8 \%$ \\
\hline 31 & 豊田蒂 & 81 & $3.9 \%$ & $4.7 \%$ & $4.0 \%$ & $3.1 \%$ & $2.9 \%$ & $4.6 \%$ & $3.5 \%$ & $4.6 \%$ & $3.5 \%$ & $3.9 \%$ & $4.4 \%$ & $3.6 \%$ & $3.7 \%$ & $4.5 \%$ & $3.3 \%$ & $4.2 \%$ \\
\hline 32 & 買る & 80 & $3.8 \%$ & $4.2 \%$ & $3.7 \%$ & $3.6 \%$ & $4.5 \%$ & $3.7 \%$ & $3.5 \%$ & $3.3 \%$ & $3.9 \%$ & $4.2 \%$ & $4.1 \%$ & $5.3 \%$ & $2.6 \%$ & $4.8 \%$ & $3.5 \%$ & $3.4 \%$ \\
\hline 33 & ウイッツ & 72 & $3.5 \%$ & $3.6 \%$ & $3.2 \%$ & $3.5 \%$ & $3.0 \%$ & $3.9 \%$ & $3.0 \%$ & $3.0 \%$ & $3.6 \%$ & $3.7 \%$ & $3.8 \%$ & $3.5 \%$ & $3.2 \%$ & $3.1 \%$ & $3.6 \%$ & $3.5 \%$ \\
\hline 34 & 丈夫 & 71 & $3.4 \%$ & $4.2 \%$ & $2.9 \%$ & $3.1 \%$ & $2.5 \%$ & $4.2 \%$ & $2.6 \%$ & $2.2 \%$ & $3.5 \%$ & $4.4 \%$ & $2.9 \%$ & $3.3 \%$ & $4.0 \%$ & $2.1 \%$ & $4.0 \%$ & $3.9 \%$ \\
\hline 35 & 技術 & 71 & $3.4 \%$ & $4.5 \%$ & $4.4 \%$ & $1.8 \%$ & $3.8 \%$ & $3.1 \%$ & $3.7 \%$ & $3.7 \%$ & $2.9 \%$ & $4.0 \%$ & $5.1 \%$ & $3.5 \%$ & $2.0 \%$ & $3.8 \%$ & $3.3 \%$ & $3.2 \%$ \\
\hline 36 & 天襌莗 & 70 & $3.4 \%$ & $2.9 \%$ & $2.7 \%$ & $4.3 \%$ & $2.3 \%$ & $3.0 \%$ & $5.4 \%$ & $4.1 \%$ & $3.8 \%$ & $1.9 \%$ & $3.2 \%$ & $3.6 \%$ & $3.3 \%$ & $2.3 \%$ & $3.1 \%$ & $4.9 \%$ \\
\hline
\end{tabular}

ワード）は表ー5のとおりである。

この表について，件数は何人がそのキーワ

ードを言及しているのか，ということであり， 出現確率はサンプル全体のうちでそのキーワ

一ドに言及している人の比率である。また表 頭の「強さ・重厚さ」の高中低は, 各サンプ ルの因子得点区分セグメントを表しており，
これとキーワードの交わるセルの比率は，セ グメントごとの各キーワードの出現確率を表 している。また黄色のハッチングは出現確率 が統計的に有意に高い（片側 5\%，一部従属な 比率の検定に基づく）セルであり，したがっ て当該の表頭セグメントの人は，当該表側キ ーワードに言及しやすい，ということを表し 
ている。例えば「カローラ」は 2079 人のうち 343 人によって言及されており，これは全体

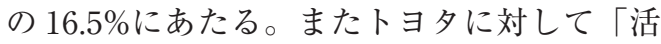
動性」イメージが強い人は,「カローラ」を連 想する確率が有意に高い (19.7\%) ことが伺え る。なお紙面の関係から 70 件以上の件数を持 つ上位 36 キーワードのみを表示した。

この結果から，例えばトヨタに対して相対 的に「強さ・重厚さ」イメージが強い人には 「世界」「安心」「クラウン」「高級」「レクサス」 「環境」「プリウス」などのキーワードが有意 に高い確率で連想されており，逆に「多い」 「大衆車」といったキーワードが，相対的にイ メージが弱い人に高い確率で連想されている ことが分かる。また同様に，「人の良さ・信頼 感」イメージが強い人には「安心」「クラウン」 「信頼」「環境」「広告」などのキーワードが, 「個性・若さ」因子が強い人には「世界」「八 イブリッド」「F1」「プリウス」などのキーワ ードが有意に高い確率で連想されており, 各
因子について，イメージ特性と連想との間に は妥当な関連性があるように解釈できた。こ れは，本研究の前提となる「消費者のブラン ドに対する印象形成モデル」によれば，これ らのキーワードが端的に表しているブランド 知識というものが, それぞれトヨタのイメー ジ特性の形成にプラスおよびマイナスの影響 を及ぼしている結果であると推測される。も ちろん，例えば「信頼感」が弱くなったとす ると, リコールや品質が悪化しているという 情報ばかり目につくなど，逆に，既に持って いるイメージ特性が情報探索などに影響を及 ぼし，知識の傾向性を規定してしまう側面も あるため，ここで導出されたキーワードが既 有のブランドイメージ特性の結果となってい ることもあり得るが，いずれにせよ，連想や 知識とイメージ特性との間には，相互に密接 な関係があることが伺えよう。

\section{4. まとめ}

口図-3

分析結果の概略

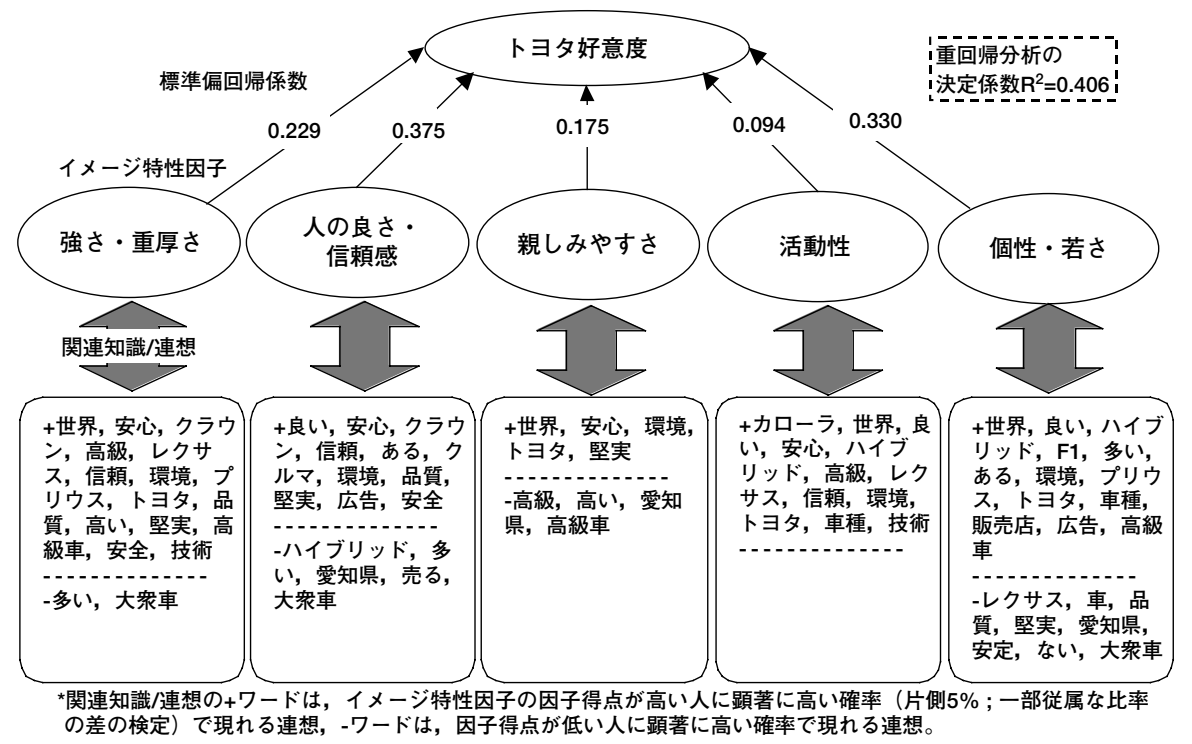


以上の分析は, 図ー3のようなフローチャ ートにまとめることができる。

本研究の調査仮説について考察すると, ま ずH1「単一ブランド（トヨタブランド）に対 する印象の個人差の因子分析結果は, 既存の 対人認知構造の分析結果と類似している」に ついては，分析の中で考察したように，類似 構造が認められる。

次に $\mathrm{H} 2\lceil$ 各人のあるブランドに対する全体 的態度 (好意度) は，ブランドのイメージ特 性をどのように感じているのかによって影響 を受ける」については, 非常に強いとはいえ ないかもしれないが，それなりに説明力を持 っていることが明らかとなった。

最後に H3「各人の, 単一のブランドに対す るイメージ特性の差は, ブランド連想の差と 関連性があり，かつそれらの間には妥当性が ある」についても，多くのキーワードがイメ ージ特性と敏感に関連しあっていることが明 らかとなった。また解釈的にではあるが，こ こで導出されたキーワードは, トヨタブラン ドの動向や消費者の反応といった背景的知識 から考えても，妥当性の高いものであった。 ただし関連性があることが，そのまま直接的 な因果関係を表現しているわけではない点に は注意が必要である。

\section{5- 考察と今後の展開}

本研究では, まず対人認知構造の諸研究を 応用し,「消費者のブランドに対する印象形成 モデル」を構成した。次にトヨタブランドを ケーススタディとして，このモデルに即する 形で（順序は逆であるが），どのようなブラ ンド連想の要素たるキーワードが各イメージ
特性と関連し，また各イメージ特性がどの程 度好意度に結びっくのかということを系統的 に分析した。特にブランド連想とイメージ特 性の関連性分析については，テキストマイニ ングの技術を用いた。これはイメージ特性の 原因や根拠となるようなブランド知識の内容 を具体化していく試みでもあった。

以上を踏まえ, 本研究全体を通じた課題と して次の三点が挙げられる。

まず，ブランドに関する知識とイメージ特 性の関連性分析について，より精度と信頼性 を向上させるための分析方法論の改良である。 これには，ブランド知識以外で消費者間の認 知プロセスの差異を生み出すような要因をな るべく統制した分析フレームを形成しなけれ ばならない。例えば性年代，ライフスタイル や購入重視点，欲しい車型などが類似してい ることなどを統制要因として設けた方が，よ り厳密にブランド知識のインパクトを計測で きると考えられる。また更に，自由回答分析 のみならず，そこから得られた「気づき」を 反映させた確認的な選択肢的アンケート調查 や質的調查を重層的に加えることで，このよ うな結果の確からしさを検証可能となる。

次に, 今回は個々のブランド知識（連想） の各要素とイメージ特性との関係に焦点を絞 つて議論を進めたが，本来，人々の知識は 個々ばらばらに記憶されているのではなく， 相互に関連した何らかの構造やかたまりの中 で保持されていると想定できる（池田・村田, 1991）。したがってこの想定される知識群，す なわち意味ネットワーク，フレーム，スキー マ，スクリプト，カテゴリーといった様々な 概念的知識構造体（新倉, 2005）とブランドイ メージ特性や好意度との関係性についての分 
析方法が次の課題となる。特にネットワーク 構造をどのように表現するのか（例えば知識 間の関連性はキーワード間の共起頻度に基づ くのか，あるいは他の指標を用いるのかなど） ということについても考察が必要である。

最後に，今回はあくまでもある単一のブラ ンドに対する消費者間のイメージの差に着目 して分析を行った。しかしながら一方で，や はり複数のブランド間で同様な分析ができな いのかということも課題となる。

この課題に対し，パーソナリテイイメージ 因子（イメージ特性）の導出については，い くつかの仮定を置きつつ複数ブランドに対す る因子分析を一度に行う，あるいは三元配置 の因子分析を利用するなどの方法で対処する ことが可能であるが, 自由連想については, そこから導出される結果そのものでは多様す ぎて分析が困難である。例えばトヨ夕で「カ ローラ」「信頼できる」「業績」といった連想 が抽出され，一方日産で「ゴーン社長」「スカ イライン」「フェアレディ」といった連想が抽 出されたとしても，そのままでは比較できな い。したがって，「カローラ」「スカイライン」 「フェアレディ」は「製品モデル」,「信頼でき る」は「属性」,「ゴーン社長」は「人物」と いったように，何らかの基準に基づいた，ブ ランド間で通用するようなアフターコーディ ング（カテゴリー化）が必要となる。要する に妥当性と信頼性をもったアフターコーディ ングの基準の開発が必要である。

以上, 本研究の課題を考察してきたが, 総 じて, 他のアンケート調查分析方法論と比較 したテキストマイニングの長短の深い考察と, ブランド連想の要素として抽出されたキーワ ード相互間の関係を妥当性の高い基準で構造
化することが, 今後, ブランドの構造を知識 構造論的に明らかにしていく上で必要になっ てくると考えられる。

謝辞

本研究を行う上で, 特性形容詞尺度の著作 権者である椙山女学園大学の林文俊先生には, 快く利用許諾をいただくとともに, 参考文献 などについての助言もいただきました。また 質問紙作成，分析方法などにつきましては， 慶應義塾大学の桑原武夫先生に多くの助言を いただきました。両先生に謹んでお礼申し上 げます。

\section{注}

1） 3Cバイアスとは，ブランドの発信者と受信者たる 消費者との間に発生する認知的なギャップを生み 出すバイアスのこと。「消費者バイアス」「競争バ イアス」「コミュニケーション・バイアス」の三つ から構成される。このうち「消費者バイアス」と は, 当該ブランドに対する消費者個人によるバイ アスのことである。「競争バイアス」とは, 当該ブ ランドの競争的ポジショニングによるバイアスで ある。最後に,「コミュニケーション・バイアス」 とは, 当該ブランドのコミュニケーションにかか わるバイアスである。より詳細には新倉（2005） などを参照いただきたい。

\section{参考文献}

Aaker, J. (1997) , "Dimensions of Brand Personality", Journal of Marketing Research, 34 (August) , 347357.

Aaker, J., Benet-Martinez, V., \& Garolera, J. (2001), "Consumption Symbols as Carriers of Culture: A Study of Japanese and Spanish Brand Personality Constructs", Journal of Personality and Social Psychology, 81 (3) , 492-508.

阿久津聡・石田茂（2002）, 『ブランド戦略シナリ オ』,ダイヤモンド社.

青木幸弘 （1993），「「知識」概念と消費者情報処理」， 『消費者行動研究』,1（1）,1-18.

朝野熙彦（2003），「マーケティングにおけるデー夕 解析の実践」,『HALBAUによる多变量解析の実 
践』,高木廣文・柳井晴夫編, 現代数学社 pp. 81-94.

Caprara, G. V., Barbaranelli, C., \& Guido, G. (2001), "Brand Personality: How to make the metaphor fit?" Journal of Economic Psychology, 22, 377-395.

Chen, A. C-H. (2001) , "Using free association to examine the relationship between the characteristics of brand associations ", Journal of Product \& Brand Management, 10 (7) , 439-451.

Collins, A. M. \& Quillian, R. (1969) , “Retrieval time from semantic memory. Journal of Verbal Learning and Verbal Behavior” , 8, 240-247.

神宮英夫（1996），『印象測定の心理学』, 川島書店.

後藤こず恵（2006），「ブランド態度形成におけるブ ランド・パーソナリティの役割 - 共分散構造分 析を用いた製品カテゴリー間比較 -」, 『関西大学 商学論集』,50（6）,97-110.

林文俊（1978），「対人認知構造の基本次元について の一考察」,『名古屋大学教育学部紀要』, 25, 233247.

林文俊・大橋正夫 ·廣岡秀一（1983），「暗黙裡の性 格観に関する研究」, 『実験社会心理学研究』,23 (1) ,9-25.

唐沢穣 - 池上知子・唐沢かおり - 大平英樹 （2001）, 『社会的認知の心理学』,ナカニシヤ出版.

Keller, K. L. (1998) , Strategic brand management : building, measuring and managing brand equity, Prentice Hall (邦訳:恩蔵直人・亀井昭宏, 『戦略的ブ ランド・マネジメント』,東急エージェンシー, 2000).

Krishnan, H. S. （1996）, "Characteristics of memory associations: A consumer-based brand equity perspective", International Journal of Research in Marketing, 13, 389-405.

松田千恵子（2003），「日本的ブランドパーソナリテ イの測定」，『ブランドリレーションシップ』,法 政大学産業情報センター・小川孔輔編, 同文館出 版.

松下光司 (2004) ,「ブランドのシンボリック・ベネ フィットと消費者行動」,『マーケティング・リボ リューション』,和田充夫・新倉貴士編, 有斐閣.

宮本聡介（2001），「対人認知」，『心理測定尺度集 II』,堀洋道監修, 吉田富二雄編, サイエンス社 pp. $2-13$.

那須川哲哉（2006），『テキストマイニングを使う技術 /作る技術：基礎技術と適用事例から導く本質と活 用法』, 東京電機大学出版局.

新倉貴士（2005），『消費者の認知世界』，千倉書房. 坂元章（1998）, 「人物表象の形成と使用 体制化と
接近可能性」，『社会的認知』,山本眞理子 - 外山 みどり編,有斐閣アルマ.

清水聰（2006），『戦略的消費者行動論』, 千倉書房.

Trope, Y. (1986) ," Identification and Inferential Processes in Dispositional Attribution” , Psychological Review, 93, 239-257

Tulving, E. (1983) , Element of Episodic Memory, Oxford University Press (邦訳:太田信夫，『タルヴ イングの記憶理論』, 教育出版, 1987）.

上田隆穂・黑岩祥太・戸谷圭子・豊田裕貴（編） （2005），『テキストマイニングによるマーケティ ング調査』, 講談社.

山本眞理子 - 原奈津子（2006），『他者を知る - 対

人認知の心理学』, サイエンス社.

黒岩 祥太(くろいわしょうた)

2001 年慶應義塾大学大学院政策・メディア研究科後 期博士課程単位取得。同年, 株式会社現代文化研究 所に入社。現在, 株式会社現代文化研究所第二研究 本部に在籍。

専門はマーケティング調査, データ解析, ブランド 論。

e-mail : s-kuroiwa@gendai.co.jp 